\title{
Socioeconomic Impacts of FMIS after Rehabilitation: Case Study of Bakultar Irrigation Project, Mahadevsthan, Dhading
}

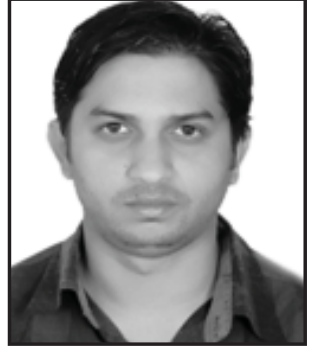

Dharma Raj
Bagale has
comple ted
M.A. in Rural
Development
from Mid-

Western University, Surkhet and B.E. in Agriculture Engineering from Institute of Engineering, Tribhuvan University. $\mathrm{He}$ is currently working as Junior Professor in the Department of Civil \& Rural Engineering at Nepal Engineering College since March 2016. His field of research interest is Integrated Water Resource Management (IWRM). Apart from academic activities, he is also involved in the study of various irrigation and renewable energy projects.

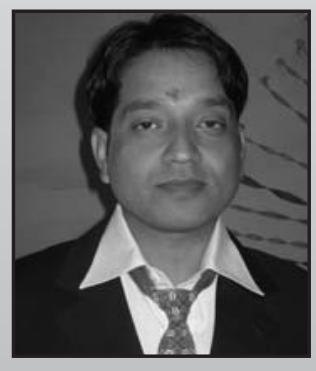

Lal Krishna

$\mathrm{BC}$ is an

Assistant

Professor

at Central

Campus

of Humanities and Social

Sciences, Mid-western University,

Surkhet. He has received his

Master's degree of Arts in Rural

Development from Tribhuvan

University.

\author{
Dharma Raj Bagale ${ }^{1}$, Lal Krishna BC ${ }^{2}$ \\ ${ }^{1}$ Department of Civil \& Rural Engineering, Nepal Engineering College (nec), \\ Changunarayan,Bhaktapur, Nepal, dharma.bagale@gmail.com \\ ${ }^{2}$ Central Campus of Humanities and Social Sciences, Mid-Western \\ University, Birendranagar, Surkhet, Nepal,lk_bc8@yahoo.com
}

\begin{abstract}
The main purpose of the study is to focus on the socioeconomic impacts of rehabilitation of Bakultar Irrigation Project in the Mahadevsthan, Dhading district, Nepal. Primary information was collected through household survey, Key Informant Interview, and FGD. Both qualitative and quantitative techniques were used for data analysis. The rehabilitation intervention of the irrigation project has changed the cropping pattern and increased the crop productivity. The cropping intensity has increased to $244.6 \%$ from $174 \%$. The study shows that rehabilitation of irrigation project has positive impact over poverty reduction, food sufficiency, gender equity, migration control and reduction of women's drudgery in household works.
\end{abstract}

Keywords : Agriculture, Irrigation, FMIS, Rehabilitation, Socioeconomic impacts

\section{INTRODUCTION}

Agriculture forms the backbone of Nepali economy, contributing about $34.35 \%$ in the GDP and providing direct or indirect employment for two-third of the population [4]. Irrigation plays vital role in agricultural productivity enhancement. Of the country's total cultivable area 2,641,000 hectares, two-third is potentially irrigable but irrigation facility is available to only a total area of $1,362,000$ hectares and merely $36 \%$ of irrigated area has year round irrigation [3]. The crop productivity under rain fed condition is fairly low as compared to irrigated. Therefore, it is necessary to increase areas under irrigation through new projects or improving the efficiency of existing projects. The development of irrigation projects in Nepal are mainly done by Government Organizations, Non-government Organizations and water users. The government's ultimate aim is to provide year round irrigation facilities and increase - irrigated areas of the country. But the impact of irrigation in any area needs to be assessed for further investments. 
This study focused on the socioeconomic impacts of "Bakultar Irrigation Project" located at Mahadevsthan, Dhading after its rehabilitation. It has a net command area of 29 ha, extracting $75 \mathrm{lps}$ water from perennial source of the Malekhu River.

\section{METHODOLOGY}

\section{A. Research Design}

The study is based on descriptive as well as exploratory research design. It describes the situation of farmers and assesses the socioeconomic impacts after the rehabilitation of the irrigation project.

\section{B. Study Area}

The study area lies in the Mahadevsthan of Dhading district, Nepal. It is accessible through a gravel road of about $10 \mathrm{~km}$ distance from Malekhu in the Prithivi Highway.

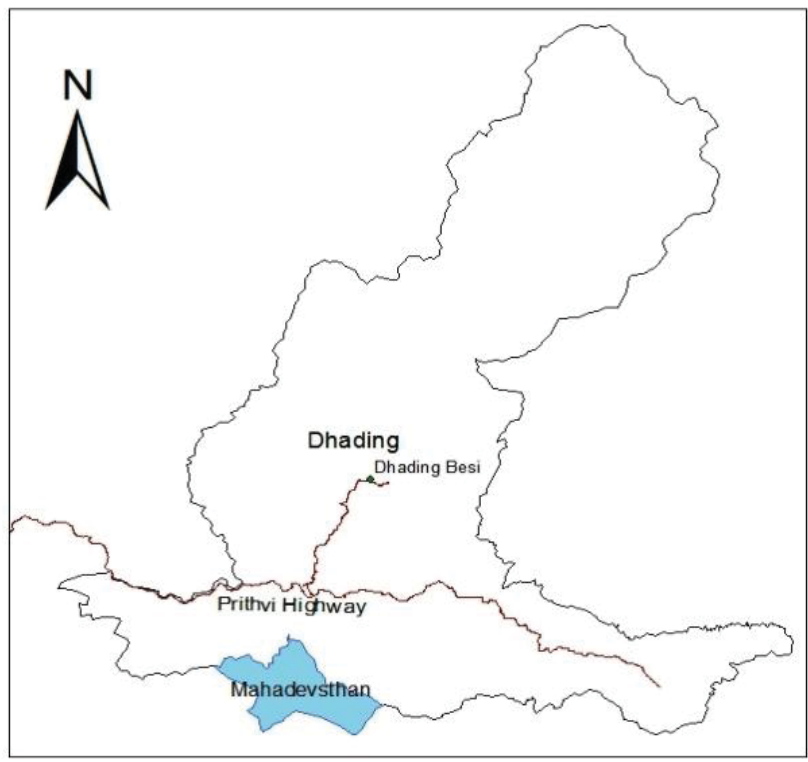

Fig. 1: Location Map of the Study Area

\section{Universe and Sample}

The project area covered a total of 58 households (HHs) only, therefore all the HHs were selected for the study adopting census method. The perception of the people at head, middle and tail of the irrigation system was given equal attention as the availability of water may usually low at tail than head reach.

\section{Methods of Data Collection}

The study is based on both primary and secondary data collected during the period of May to July 2016.

\section{Primary Data:}

The primary information was collected via household survey, Focus Group Discussion with water user association (WUA), Key Informants Interview with project officials.

\section{Secondary Data:}

Secondary data regarding the rehabilitation of the irrigation project was obtained from Department of Irrigation (DOI), Irrigation Development Division (IDD) and District Agriculture Development Office (DADO), Dhading.

\section{E. Data Processing and Analysis}

After collecting data, the calculations related to analysis were performed with the help of MS Excel. Both qualitative and quantitative techniques were used for data analysis.

\section{III.RESULTS AND DISCUSSION}

\section{A. Overview of the Irrigation System}

Bakultar Irrigation Project is a Farmer Managed Irrigation System (FMIS). According to local people, this is a century old system but not functioning since some decades. The farmers started functioning of the canal again in the year 2062 B.S. and also constructed the main canal by mobilizing local resources themselves. But most part of the main canal was unstable due to seepage and landslide. The rehabilitation work was started on $15^{\text {th }}$ Ashwin 2068 B.S. and was completed on $15^{\text {th }}$ Chaitra 2069 B.S. partly by the WUA and partly by the contractor [2].

\section{B. Landholding and Land Tenure System}

Most of the households in the project area were land owners but there were tenants too, who work as labor force. The land distribution in the command area was not uniform. Figure 2 shows land holding size of farmers. 


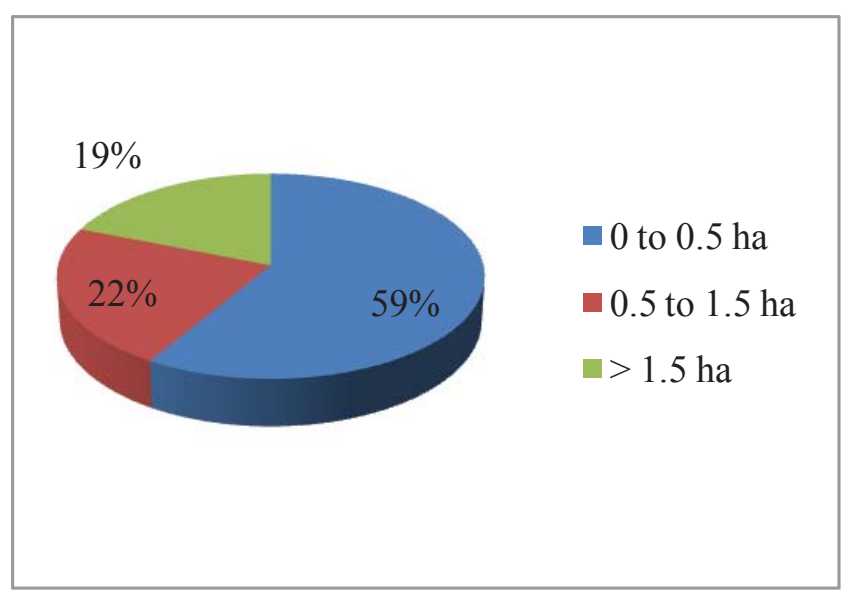

Fig.2: Land Holding Size of Farmers

\section{Occupation, Income and Expenditure}

Regarding the source of income, it was found that agriculture was the main source of income. It is followed by services, foreign employment, business, wages and others. Figure 3 presents the occupation of farmers.

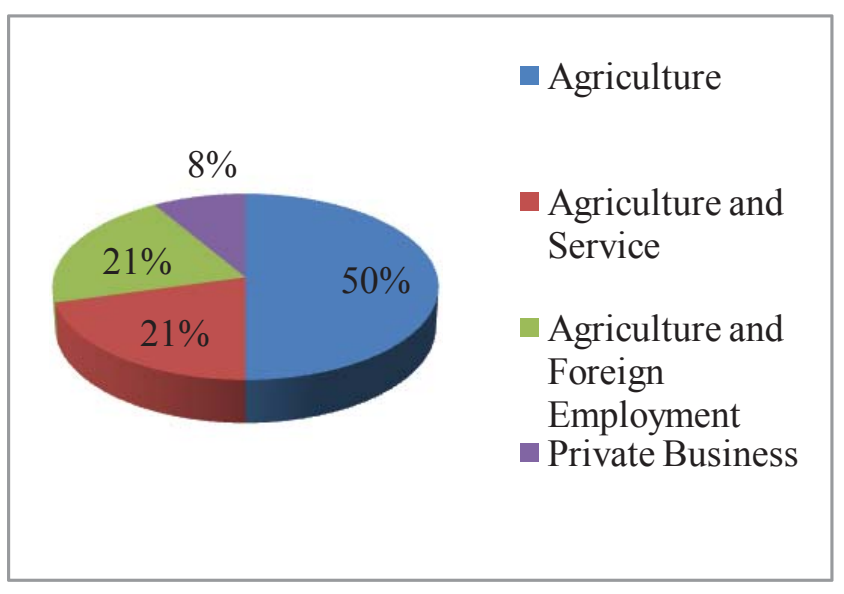

Fig. 3: Source of Income of Farmers

The average annual household income was found to be NRs 274,700 while the average annual expenditure was NRs 196,225.

\section{Change in Cropping Pattern}

It was found that the cropping pattern has been changed in the area due to the rehabilitation of irrigation project. Paddy-Vegetable, PaddyFallow-Maize, and Paddy-Vegetable-Maize were the general cropping pattern in the project area. Before irrigation, hardly two crops were grown in a year. The winter crops like mustard, wheat and vegetables; and paddy, also in spring, are possible only after rehabilitation of irrigation system. PaddyMustard-Paddy, Paddy-Mustard-Maize, PaddyWheat-Maize and Paddy-Mustard-Vegetables are the cropping pattern after the rehabilitation of the project. The vegetables grown in the project area mainly include cabbage, cauliflower, sponge gourd, bitter gourd, okra, potatoes, etc.

\section{E. Change in Cropping Intensity}

Cropping intensity is the ratio of total area of harvested crop to total available land, and is reported in percent. The change in cropping intensity is only possible due to irrigation facility. So, the direct effect of irrigation can be visualized with increase in cropping intensities. The figure 4 demonstrates the comparison of cropping intensity during different season before and after rehabilitation of the project.

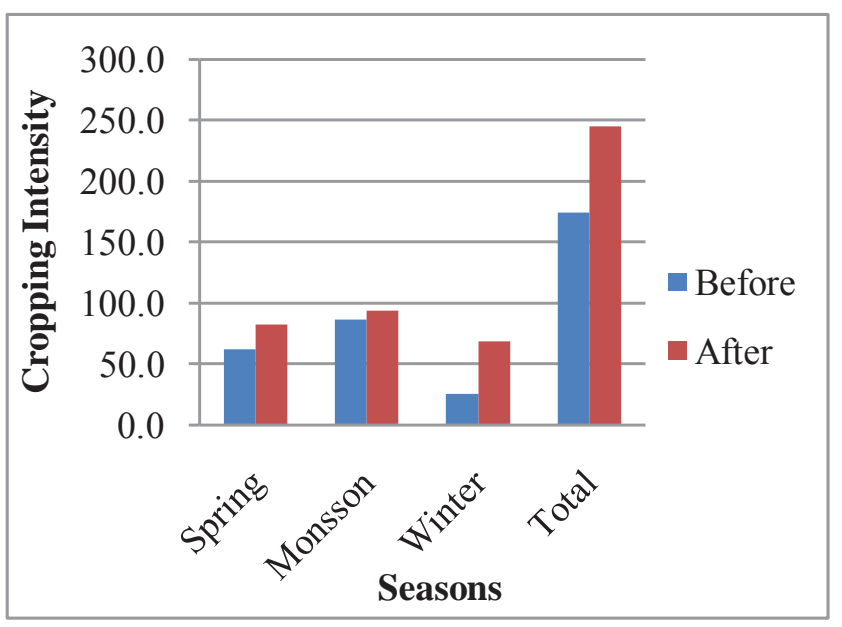

Fig. 4: Cropping Intensity Before and After Project Rehabilitation

The cropping intensity changed to $244.6 \%$ from $174.1 \%$ after project rehabilitation. The increase in cropping intensity is due to availability of water during winter and spring season.

\section{F. Agriculture Production and Productivity}

Paddy and Maize are the major crops grown during spring season. The average production of paddy increased to 3.9 from $2.8 \mathrm{mt} / \mathrm{ha}$ and that of maize to 1.9 from $1.1 \mathrm{mt} / \mathrm{ha}$. During monsoon season, paddy is the major crop grown. The average production of paddy increased to 3.8 from $1.3 \mathrm{mt} /$ ha. Mustard, wheat, vegetable are major crops grown during winter season. The average 
productivity of mustard, and wheat are 0.4 and $1.5 \mathrm{mt} / \mathrm{ha}$, respectively. The average productivity of vegetables increased to 9.2 from $\mathrm{mt} /$ ha after the rehabilitation of the project. The increase in crop productivity is mainly due to water availability, use of hybrid varieties of paddy and maize replacing the local varieties, and the use of fertilizers.

\section{G. Socioeconomic Impacts}

The long term impacts due to rehabilitation of irrigation project are poverty reduction in the project area, sufficiency of food items in farmers' household, shift of occupation from farm to off farm, reduction of women's drudgery in household works, gender issue and migration control. The socioeconomic impacts of Bakultar Irrigation Project after rehabilitation are described as follows.

\section{Income from Agriculture Production:}

Most of the farmers usually depend on agriculture for their main income. After rehabilitation of the irrigation project, agricultural production increased, which ultimately raised the income of individual farmer. The increase in income is dependent on size of landholdings. The farmers with large land holdings have given their land in lease and got involved in animal rearing and horticulture. Similarly, the farmers with small landholding have taken others' land in lease to meet their food demand. However, the income is not substantial as the farmers are lagging in the diversification of cropping and problem to access direct market. Each individual farmer have to take his/her agricultural production in the Malekhu Bazar, some $10 \mathrm{~km}$ away from the project area. This is due to unavailability of collective method of marketing. This deprived farmers of getting fair price for their production. The comparison of household with income from agriculture before and after project rehabilitation is illustrated in Table I.

TABLE I

INCOME FROM AGRICULTURE BEFORE AND AFTER THE PROJECT REHABILITATION

\begin{tabular}{|l|c|c|c|c|}
\hline $\begin{array}{c}\text { Income from } \\
\text { Agriculture (NRs '000) }\end{array}$ & $0-20$ & $20-50$ & $50-100$ & $\begin{array}{c}\text { above } \\
100\end{array}$ \\
\hline Nos. of HHs Before & 28 & 16 & 11 & 3 \\
\hline Nos. of HHs After & 8 & 12 & 22 & 16 \\
\hline
\end{tabular}

\section{Poverty Reduction}

The reduction in poverty is directly related with income from agriculture production, employment opportunity created by the project, sufficiency of food items, level of expenditure on education, sanitation, health services, purchasing of durable goods and construction and maintenance of houses. From the data presented above, reduction in poverty in the study area is as shown in figure 5 .

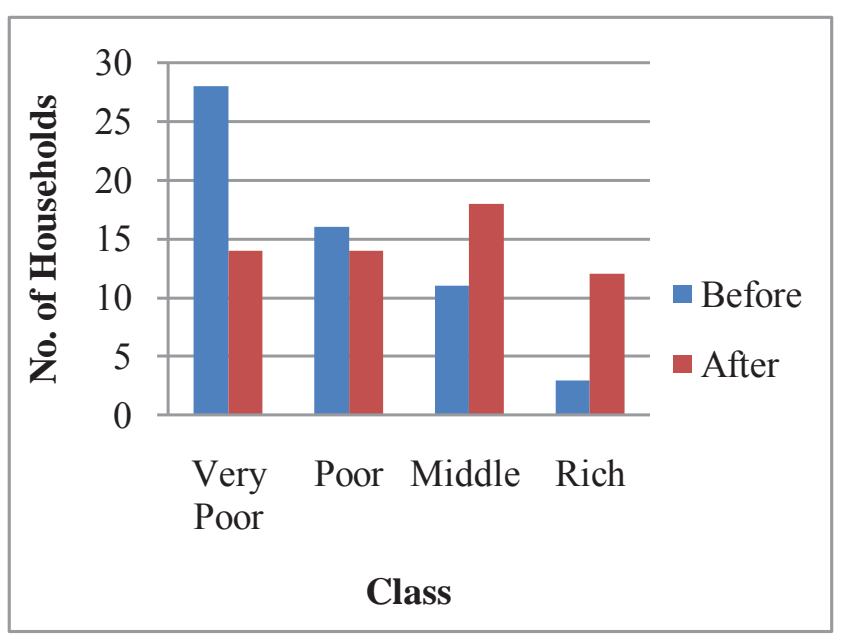

Fig. 5: Comparison of Poverty Level before and after Rehabilitation

\section{Employment:}

The rehabilitation of the irrigation project created both short term employment during construction period and long term employment due to productive use of new irrigated land and intensification of the crop production. Almost 20$30 \%$ of the total project cost was covered by labour (both skilled and unskilled).The rehabilitation project also generated employment opportunities for inactive work force, semi-skilled and mostly unskilled, striving for employment in project area and neighboring villages during the construction period. The land areas that remained fallow during winter season were cultivated with mustard, wheat and vegetables. Most of the farmers in project area, who used to work as labour force in neighboring village, are now engaging in their farm land throughout the year. 


\section{Food sufficiency:}

The comparative situation of food sufficiency due to the agricultural production before and after rehabilitation of irrigation system is as shown in Figure 6.

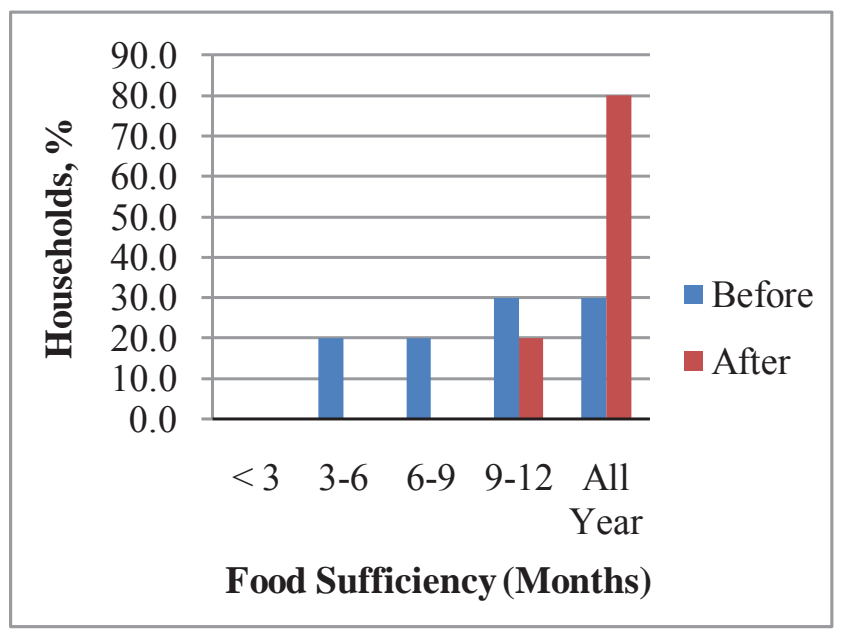

Fig. 6: Comparison of Food Sufficiency

The food sufficiency in Bakultar area indicates good progress and is increasing satisfactorily. The above figure clearly shows that the satisfactory change in food sufficiency due to rehabilitation of the project.

\section{Expenditure Level of Farmers:}

The basic education for children and health services are provided by government. But, for higher education and complex health problem, people in the area have to visit either district headquarter or Kathmandu, which is an economical burden for them and have to depend on banks, cooperative and relatives for loan. However, with the increase in the income level, the farmers have ability to disburse for basic as well as other requirements for their family members. The earning from the sales of agriculture product is mainly expended on the purchase of daily consumable food items insufficient from their farm production.

\section{Women's Drudgery}

Women in project area are main workers in agricultural farms. Due to the rehabilitation of the irrigation project, the women's drudgery has been reduced radically. Workload of most of the women is reduced due to lining of canal and ultimately lesser regular repair \& maintenance of canal. Irrigation helped timely planting of crop; reduce weed infestations especially in paddy thereby reducing the labor requirement. The time required for fetching water to their livestock is reduced.

\section{Gender Issue}

Reference [1] emphasizes on the women's involvement in water user association. But, women's involvement in decision-making does not seems enough since the beginning of the project rehabilitation. Only two women were included in the first 11 member executive committee holding one major post, i.e. vice-chairperson. Similarly, only three women were included in second executive committee of 9 members with one major post, i.e. treasurer.

However, women played active role during construction work. The majority of physical works was done by women. They participated both as labour contributions in WUA works, and as paid labour in WUA payable and contractor's works. Women are also contributing in regular repair and maintenance of the system.

Only few women are involved in meetings, trainings, and exposure visits. So, they still need support in capacity building and income generation activities.

\section{Migration}

The migration is a very challenging for developing countries like Nepal. The economically active age group is attracted for better opportunity in and outside of county, which ultimately created the manpower problem in any area.

The Bakultar Irrigation Project is somehow able to control such migration, mainly due to active population engagement in food production and employment opportunity created in the area. The seasonal migration, primarily in winter season in the Kathmandu and India is also largely reduced as the farmers are busy in their own field works.

\section{Shift of Occupation}

Due to the sufficiency of food from the farm after the rehabilitation of project, many farmers with large landholding are giving their land in lease to 
marginal farmers and they are involved in private business like vehicle services in the village, shop, animal rearing, horticulture, etc. The number of such households increased to 11 from 3 households.

\section{LESSONS LEARNED}

There are many FMISs in hilly regions of Nepal which are not working efficiently and farmers are facing huge problems to irrigate their fields. Rehabilitation of these systems can be done successfully with the participation of the water users. Increase in water availability and reliability increases the income from agriculture and ultimately can have positive impact in socioeconomic of the area. However, the WUAs are not capable for smooth operation and maintenance of the irrigation system as the Irrigation Service Fee (ISF) collection is in very poor condition. Mainly, the "water guard" appointed for operation of the system is unable to get payment on time.

The farmers are not able to earn sufficient income from their farm although the productivity has increased. It is due to the problems in market and pricing system. The middle-man gets more profits than the producers. Therefore, appropriate mechanism is needed so that farmers can get fair price for their production, through which sufficient ISF can be collected for operation and maintenance of the system.

\section{CONCLUSION \& RECOMIMENDATIONS}

\section{A. Conclusion}

The rehabilitation of Bakultar Irrigation Project has been able to increase socioeconomic condition of the area. Poverty reduction, sufficiency of food items, shift of occupation from farm to off farm, reduction of women's drudgery in household works, gender inclusion and reduction in migration are such impacts.

\section{B. Recommendations}

Improvement in agricultural inputs, such as use of hybrid seed, proper dose and timing of fertilizer etc. are highly recommended.

The farmers should focus the activities to develop the project area as organic farming center.

Agriculture Cooperative is needed to be formed in the project area to organize the farmers and solve the market problem, so that the gap between the farmer and the market is reduced and farmers can enjoy the fair price of their produce.

\section{REFERENCES}

[1] GoN,Irrigation Policy. Kathmandu: Government of Nepal,2060.

[2] IDD Dhading,.Bakultar Irrigation Project:Detail Project Report. Dhading: Department of Irrigation,2011.

[3] NPC, Three Years Plan(2014-2016). Kathmandu: National Planning Commission, 2014.

[4] World Bank, Nepal Report. Washington DC: The World Bank, 2014. 